\title{
SPEED SENSORLESS DIRECT TORQUE CONTROL OF INDUCTION MOTOR DRIVE
}

\author{
E. E. El-Kholy \\ Electrical Engineering Department, Faculty of Engineering, \\ Shebin El-kom, Minoufiya University, Egypt. \\ e-mail: eelkholy@hotmail.com
}

\begin{abstract}
:
A torque and speed control system for pulse width modulated inverter fed induction motor without speed sensor is proposed. The system is implemented by adding a speed calculation algorithm to the direct torque control (DTC) technique, based on the instantaneous space vector control theory. These control strategies guarantee very good dynamic and steady state characteristics, with low sampling time and constant switching frequency. A laboratory control unit with Digital Signal Processor (DSP) scheme is presented. A simulation and experimental results are presented and they agree very well.
\end{abstract}

\section{KEYWORDS:}

Speed Sensorless, Direct Torque Control (DTC), Induction Motor Drives, Space Vector Modulation (SVM), Pulse Width Modulation (PWM), Model Reference Adaptive System (MRAS).

\section{SYMBOLS:}

$\begin{array}{ll}\mathrm{d}, \mathrm{q} & : \text { Subscripts denoting arbitrary rotating axis. } \\ \mathrm{E}_{\mathrm{d}} & : \text { DC link voltage of the inverter. } \\ \mathrm{e}_{\mathrm{m}} & : \text { Counter electromotive force vector. } \\ \mathrm{i}_{\mathrm{a}}, \mathrm{i}_{\mathrm{b}}, \mathrm{i}_{\mathrm{c}} & : \text { Instantaneous values of the stator current vectors. } \\ \mathrm{i}_{\mathrm{m}} & : \text { Magnetizing current vector. } \\ \mathrm{L}_{\mathrm{S}}, \mathrm{L}_{\mathrm{r}} & : \text { Self inductance of the stator and rotor per phase. } \\ \mathrm{L}_{\mathrm{m}} & : \text { Mutual inductance. } \\ \mathrm{L}_{\mathrm{S}}, \mathrm{L}_{\mathrm{lr}} & : \text { Stator and rotor leakage inductance per phase. } \\ \mathrm{K}_{\mathrm{p}} & : \text { Proportional controller gain. } \\ \mathrm{K}_{\mathrm{i}} & : \text { Integrator controller gain. }\end{array}$




$\begin{array}{ll}\mathrm{p} & : \text { Number of pole pairs. } \\ \mathrm{R}_{s} & : \text { Stator resistance. } \\ \mathrm{R}_{\mathrm{r}} & : \text { Rotor resistance. } \\ \mathrm{S}_{\mathrm{a}}, \mathrm{S}_{b}, \mathrm{~S}_{c} & : \text { States of inverter switches. } \\ \mathrm{s} & : \text { Subscript denoting stator. } \\ \mathrm{r} & : \text { Subscript denoting rotor. } \\ \mathrm{T}_{\mathrm{d}} & : \text { Electromagnetic developed torque. } \\ \mathrm{T}_{\mathrm{L}} & : \text { Load torque. } \\ \mathrm{T}_{\mathrm{r}} & : \text { Rotor time constant. } \\ \mathrm{T}_{\mathrm{s}} & : \text { Sampling time. } \\ \mathrm{V}_{\mathrm{a}}, \mathrm{V}_{\mathrm{b}}, \mathrm{V}_{\mathrm{c}} & : \text { Instantaneous values of the stator voltages } \\ \omega_{\mathrm{c}} & : \text { Supply frequency. } \\ \psi_{s} & : \text { Primary flux linkage vector. } \\ \varepsilon & : \text { Error of flux and torque. } \\ \omega_{\mathrm{r}} & : \text { Rotor velocity. } \\ \omega_{\mathrm{s}} & : \text { Velocity vector of stator flux. } \\ \sigma & : \text { Leakage coefficient. } \\ * & : \text { Subscript denoting command value. } \\ \otimes & : \text { Cross product. } \\ \wedge & : \text { Subscript denoting estimated value. }\end{array}$

\section{INTRODUCTION:}

Recently, there is an increasing demand of high-speed high-precision torque and speed control for induction motor drives. In such systems, an electromechanical speed sensor is essential to be coupled with the motor shaft to measure the rotor speed. However, the rotational sensor cannot be mounted in some cases such as motor drives in hostile environments, high-speed motor drives, etc. Also, the sensor encoder encumbers the mechanical drive, and spoils the general characteristics of the induction motor drive. From this view, a speed sensorless system is preferred [1-4].

The sensorless induction motor drives have been studied for the last two decades, and some results are already applied to industrial fields. At higher stator frequency, practically, higher than $10 \%$ of rated frequency, simple direct torque control method gives satisfactory torque control performance [5-9]. However, the drives performance has still many drawbacks compared with that of the sensor-based drives. In particular, at low stator frequency, the torque controllability is still far from satisfactory [9].

The DTC method introduced by Depenbrock et al. [10] and Takahashi et al. [11], has found many recent applications. Also one of the biggest power electronics company ABB Finland has constructed the first commercial inverter with DTC (ASC600). DTC has been developed to regulate flux and torque directly, while currents and voltages are regulated indirectly. Some of its 
advantages, like excellent dynamic performance, robustness for rotor parameter variation, no coordinate transformation and no current control loop are of particular interest.

In this paper, simulation of a proposed speed sensorless direct torque control system is presented, the system is verified experimentally and has the following specific features:

- does not require any integration of sensed variables.

- is robust to parameter thermal variations.

- can get wider bandwidth of speed control loop.

- can operate at low stator frequency.

\section{SPEED AND TORQUE CONTROL:}

\section{- Space vector modulation (SVM):}

For an inverter feeding a symmetrical three-phase induction motor without neutral connection, the instantaneous voltages generated by the inverter should satisfy the following expression,

$V_{a}(t)+V_{b}(t)+V_{c}(t)=0$

These three voltage space vectors can be represented in a two dimensional space, where the coordinates are chosen, so that the vector $\left[\mathrm{V}_{\mathrm{a}, 0,0]}\right.$ is placed along the horizontal axis, the vector $\left[0, V_{b}, 0\right]$ is delayed by $120^{\circ}$, while the vector $\left[0,0, V_{c}\right]$ is delayed by $240^{\circ}$ from phase-a. So, the three-phase instantaneous machine voltages are represented by an instantaneous space voltage vector $\left(\mathrm{V}_{s}\right)$ as $[6]$ :

$v_{s}=\sqrt{\frac{2}{3}}\left[V_{a}+v_{b} e^{j \frac{2 \pi}{3}}+v_{c} e^{j \frac{4 \pi}{3}}\right]$

On the other hand, the three phases of the induction motor may be connected to either the negative or positive rail of the DC supply, as shown in Fig.(1-a). Therefore, the possible inverter configurations are $2^{3}=8$. By using these switching functions the stator space voltage vector can be expressed as;

$v_{s}\left(S_{a}, S_{b}, S_{c}\right)=\frac{2}{3} E_{d}\left(S_{a}+S_{b} e^{j \frac{2 \pi}{3}}+S_{c} e^{j \frac{4 \pi}{3}}\right)$

Where, $\mathrm{Sa}, \mathrm{S}_{\mathrm{b}}$, and $\mathrm{S}_{\mathrm{c}}$ are the states of the upper switches $(\mathrm{S}=1$ means switch on, $S=0$ switch off). The states of the lower switches are the opposite of the upper switches to prevent any short circuit of the DC supply. According to the 
combinations of switching modes, the primary space voltage vectors $V_{s}\left(S_{a}, S_{b}\right.$, $\mathrm{S}_{\mathrm{c}}$ ) are specified for eight kinds of vectors $\mathrm{V}_{\mathrm{s}}(1,1,1),(0,0,0)$ and the others are the space nonzero active voltage vectors. i.e. $(1,0,0), \ldots \ldots \ldots(0,1,1)$, as shown in Fig. (1-b).

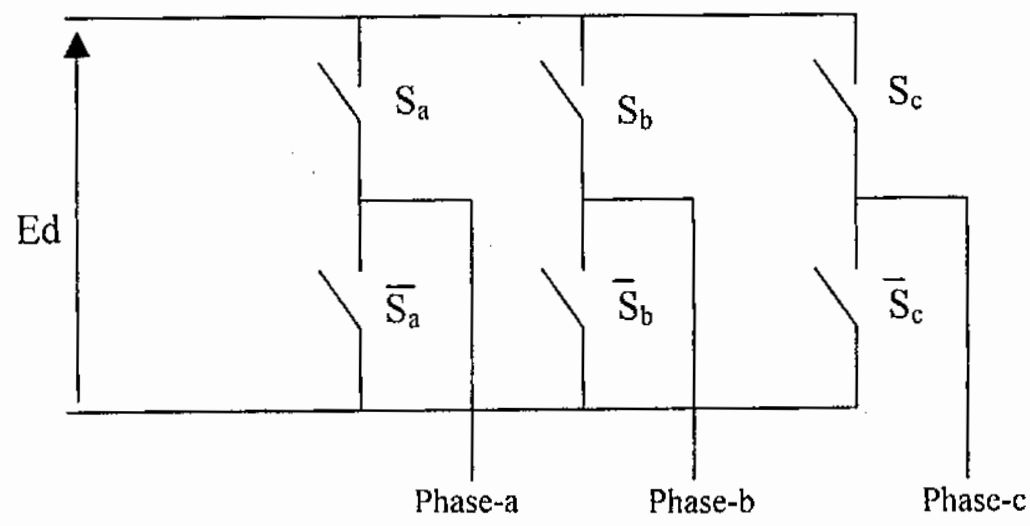

(a) Inverter switching states

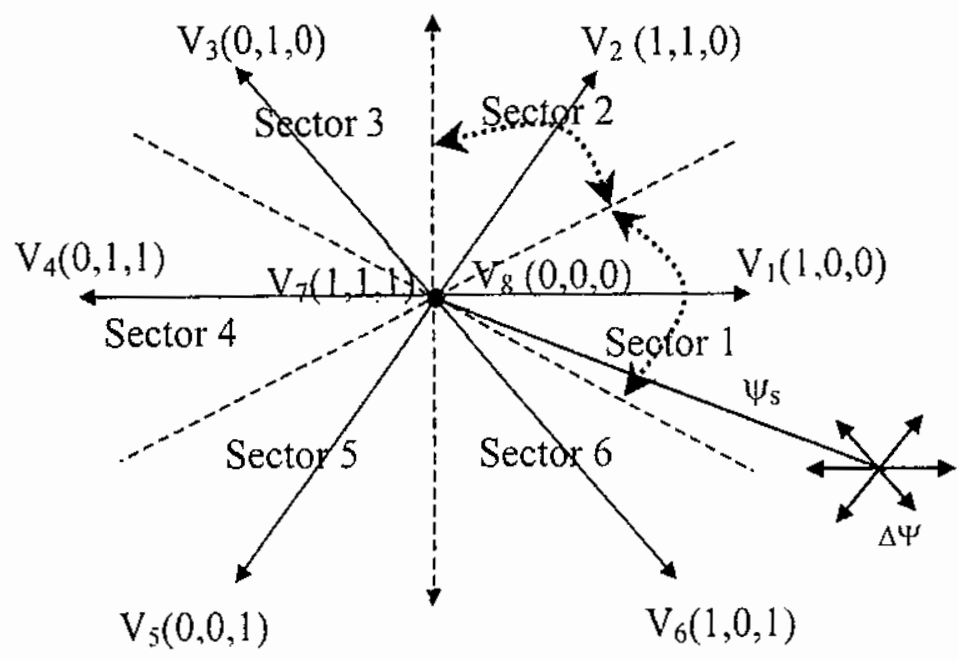

(b) Inverter space voltage vectors and corresponding stator flux variations

Fig. (1) Three-phase voltage-source inverter

\section{- Direct torque control:}

The direct torque control is a hysteresis stator flux and torque control. It directly selects one of the six non-zero and two zero voltage vectors generated by voltage source inverter in order to maintain the estimated stator flux and torque within the hysteresis bands. 
The method of flux and torque calculation is discussed as follows: With the conventional technique, the stator flux interlinkage is simply calculated using the following expression:

$$
\psi_{s}=\int\left(V_{s}-R_{s}^{i}\right) d t
$$

The motor developed torque is calculated from stator flux and current vector using the following expression:

$$
\mathrm{T}_{\mathrm{d}}=\frac{3}{2} \mathrm{P}\left(\psi_{d s} \mathrm{i}_{\mathrm{qs}}-\psi_{q s} \mathrm{i}_{\mathrm{ds}}\right)
$$

This method has a drawback that at low speed, the flux calculation errors are large because of integration drift and offset. This drawback could lead to deterioration in the torque control accuracy and an increase in torque ripples in the low speed region, thus making four-quadrant operation difficult.

Actual torque and flux values are compared with those produced by the torque and flux reference controllers. In particular, the stator flux is controlled by a two-level hysteresis comparator, whereas the torque can be controlled by a three-level hysteresis comparator as shown in Fig.(2).

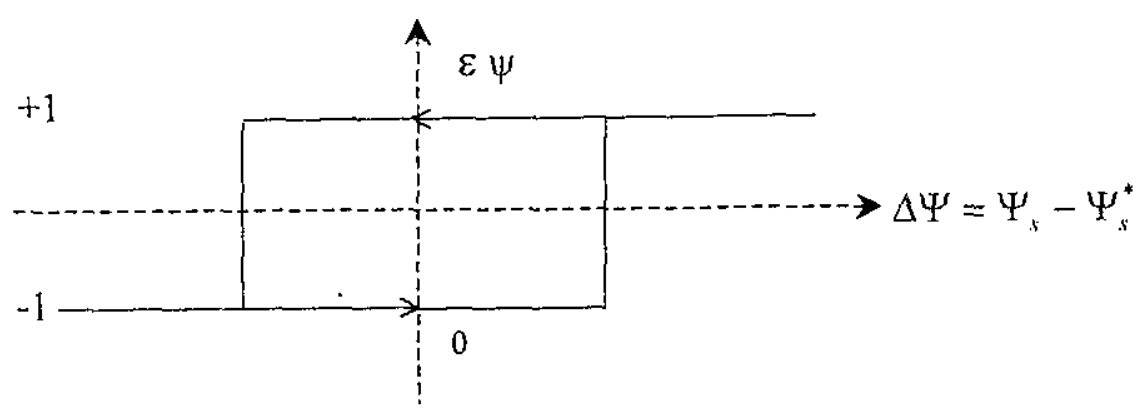

(a) Two-level flux hysteresis comparator

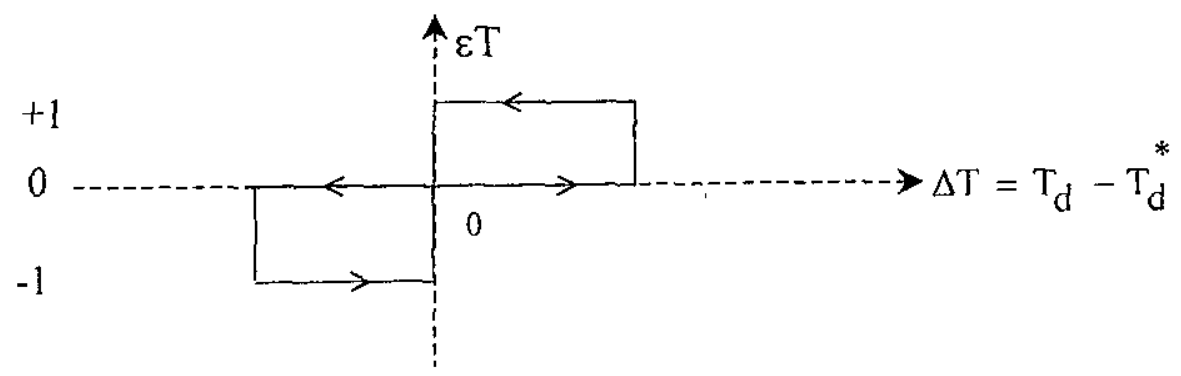

(b) Three-level torque hysteresis comparator

Fig. (2) Hysteresis comparator 
Depending on the outputs from either two-level, or three-level controllers the pulse selector directly determines the optimum inverter switch positions, according to the switching pattern given in table (1).

\begin{tabular}{|c|l|l|l|l|l|l|l|}
\hline \multicolumn{2}{|c|}{} & Sector 1 & Sector 2 & Sector 3 & Sector 4 & Sector 5 & Sector 6 \\
\hline$\varepsilon \psi=0$ & $\varepsilon_{\mathrm{T}}=-1$ & $\mathrm{~V}_{2}(1,1,0)$ & $\mathrm{V}_{3}(0,1,0)$ & $\mathrm{V}_{4}(0,1,1)$ & $\mathrm{V}_{5}(0,0,1)$ & $\mathrm{V}_{6}(1,0,1)$ & $\mathrm{V}_{1}(1,0,0)$ \\
\cline { 2 - 8 } & $\varepsilon_{\mathrm{T}}=0$ & $\mathrm{~V}_{7}(1,1,1)$ & $\mathrm{V}_{0}(0,0,0)$ & $\mathrm{V}_{7}(1,1,1)$ & $\mathrm{V}_{0}(0,0,0)$ & $\mathrm{V}_{7}(1,1,1)$ & $\mathrm{V}_{0}(0,0,0)$ \\
\cline { 2 - 8 } & $\varepsilon_{\mathrm{T}}=+1$ & $\mathrm{~V}_{6}(1,0,1)$ & $\mathrm{V}_{1}(1,0,0)$ & $\mathrm{V}_{2}(1,1,0)$ & $\mathrm{V}_{3}(0,1,0)$ & $\mathrm{V}_{4}(0,1,1)$ & $\mathrm{V}_{5}(0,0,1)$ \\
\hline$\varepsilon \psi=1$ & $\varepsilon_{\mathrm{T}}=-1$ & $\mathrm{~V}_{3}(0,1,0)$ & $\mathrm{V}_{4}(0,1,1)$ & $\mathrm{V}_{5}(0,0,1)$ & $\mathrm{V}_{6}(1,0,1)$ & $\mathrm{V}_{1}(1,0,0)$ & $\mathrm{V}_{2}(1,1,0)$ \\
\cline { 2 - 8 } & $\varepsilon_{\mathrm{T}}=0$ & $\mathrm{~V}_{0}(0,0,0)$ & $\mathrm{V}_{7}(1,1,1)$ & $\mathrm{V}_{0}(0,0,0)$ & $\mathrm{V}_{7}(1,1,1)$ & $\mathrm{V}_{0}(0,0,0)$ & $\mathrm{V}_{7}(1,1,1)$ \\
\cline { 2 - 8 } & $\varepsilon_{\mathrm{T}}=+1$ & $\mathrm{~V}_{5}(0,0,1)$ & $\mathrm{V}_{6}(1,0,1)$ & $\mathrm{V}_{1}(1,0,0)$ & $\mathrm{V}_{2}(1,1,0)$ & $\mathrm{V}_{3}(0,1,0)$ & $\mathrm{V}_{4}(0,1,1)$ \\
\hline
\end{tabular}

Table (1) Basic DTC switching states

For considering the stator flux vector lying in sector No.1, the voltage vectors $V_{2}$ and $V_{6}$ can be selected in order to increase the flux while $V_{3}$ and $V_{5}$ can be applied to decrease the flux. Among these, $V_{2}$ and $V_{3}$ determine a torque increase, while $\mathrm{V}_{5}$ and $\mathrm{V}_{6}$ a torque decrease. The zero voltage vectors are selected when the torque comparator output is zero, irrespective to the stator flux condition.

\section{- Induction motor speed estimation:}

It has been proved that a Model Reference Adaptive System (MRAS) technique is very effective in estimating motor speed [6]. In the stationary reference frame the induction motor equations can be expressed as [7]:

$$
\begin{aligned}
& \mathrm{V}_{\mathrm{S}}=\mathrm{R}_{\mathrm{S}} \mathrm{i}_{\mathrm{S}}+\sigma \mathrm{L}_{\mathrm{S}} \frac{\mathrm{di}_{\mathrm{S}}}{\mathrm{dt}}+\mathrm{e}_{\mathrm{m}} \\
& \frac{\mathrm{di}_{\mathrm{m}}}{\mathrm{dt}}=\omega_{\mathrm{r}} \otimes \mathrm{i}_{\mathrm{m}}-\frac{1}{\mathrm{~T}_{\mathrm{r}}} \mathrm{i}_{\mathrm{m}}+\frac{1}{\mathrm{~T}_{\mathrm{r}}} \mathrm{i}_{\mathrm{S}}
\end{aligned}
$$

From equations (6) and (7), the counter emf vector, $\mathrm{e}_{\mathrm{m}}$, and its estimated, $\hat{\mathrm{e}}_{\mathrm{m}}$, can be derived as follows :

$$
\begin{aligned}
& e_{m}=V_{s}-\left(R_{s i s}+\sigma L_{s} \frac{d i}{d t}\right) \\
& \hat{e}_{m}=\frac{L_{m}}{L_{r}}\left(\hat{\omega}_{r} \otimes \hat{i}_{m}-\frac{1}{T_{r}} \hat{i}_{m}+\frac{1}{T_{r}} i_{s}\right)
\end{aligned}
$$


Figure (3) shows the structure of the MRAS system using equations (8) and (9). The reference model is based on equation (8), and the adjustable model based on equation (9). The error between the outputs of the two models is then used to drive a suitable adaptation mechanism that generates the estimate motor speed for the adjustable model.

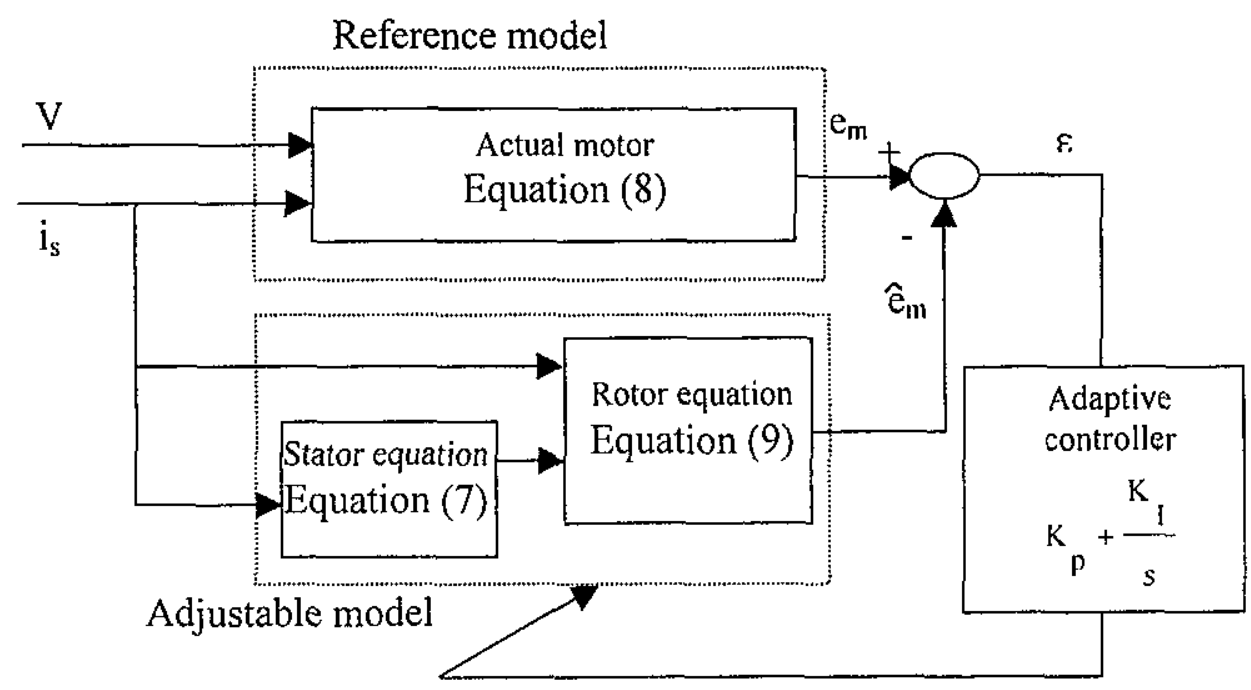

Estimated speed $\left(\hat{\omega}_{\mathrm{r}}\right)$

Fig.(3) Motor speed estimation based on MRAS

Suitable adaptation mechanism is the one which ensures that the system will be stable and the estimated quantity will converge to the actual value. It has been shown that MRAS is always stable by using the following simple adaptation mechanism.

$\hat{\omega}_{r}=\left(\mathrm{K}_{\mathrm{p}}+\frac{\mathrm{K}_{\mathrm{I}}}{\mathrm{s}}\right)\left(\hat{e}_{m} \otimes e_{m}\right)$

It is evident from equation (8) and Fig.(3) that no integration is required in the reference model of the MRAS system.

\section{SYSTEM IMPLEMENTATION:}

Figure (4) shows a schematic diagram of the induction motor drive system. The basic configuration of the drive consists of a squirrel cage induction motor fed from a voltage source inverter. The parameters of this system are given in the 
Appendix. The instantaneous speed of the primary flux linkage vector is controlled to allow the developed torque $\left(\mathrm{T}_{\mathfrak{d}}\right)$ to agree with the torque command $\left(\mathrm{T}_{\mathrm{d}}\right.$ ) within a certain error.

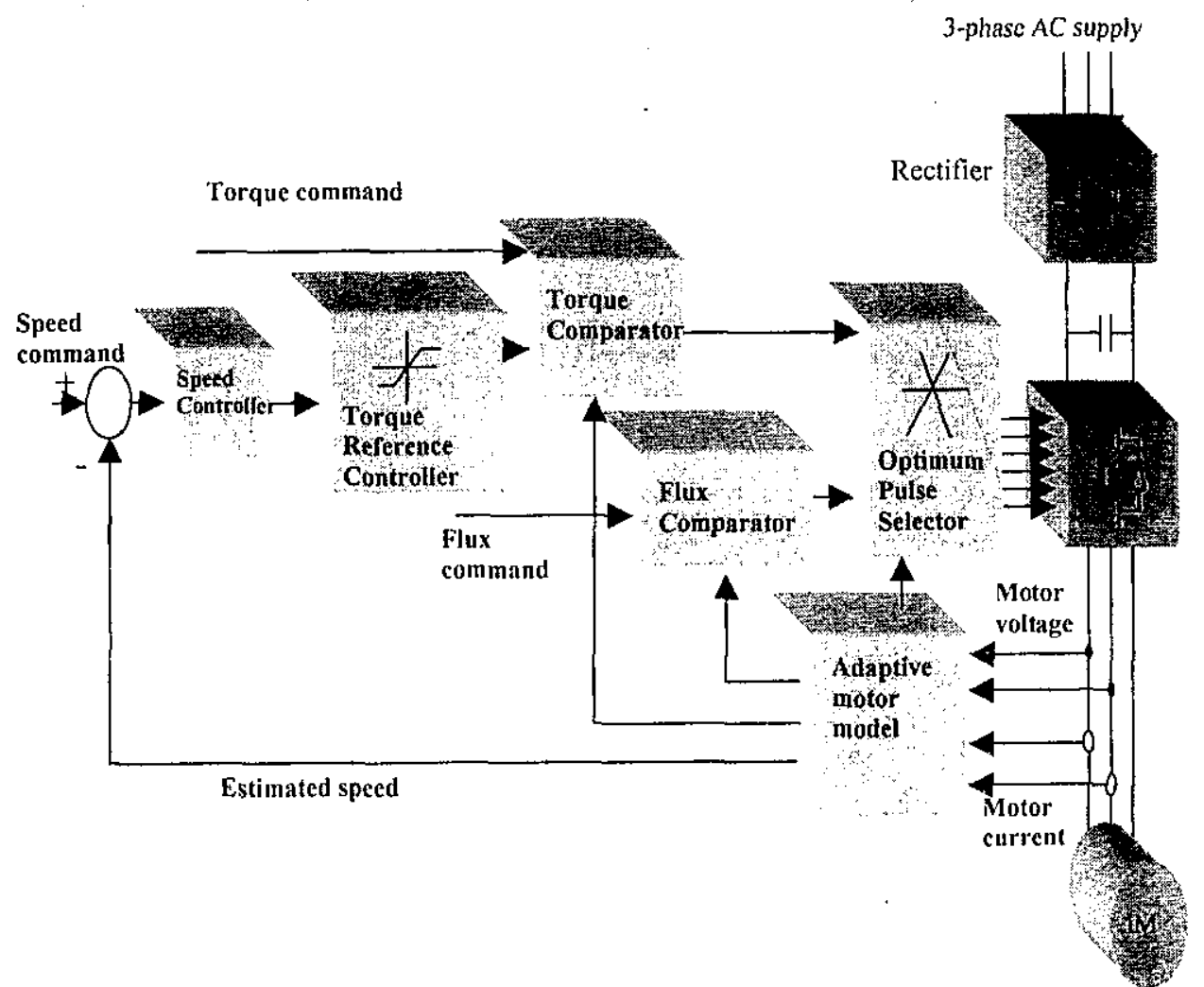

Fig. (4) Block diagram for a direct torque controlled induction motor drive without speed sensor

The full digital control scheme of the system drive is implemented on the DS1 102 controller board as shown in Fig. (5). The DSP board based on TMS320C31 as the main processor and TMS320P14 as a slave, which serves as a digital 1/O subsystem. The complete DS1102 board can be installed in a Personal Computer with a capability of uninterrupted communication with the latter through the dual-port memory, which can be used by the DSP monitor on the host PC [12]. The feedback signals to the controller board are the measured two-phase currents, two-phase voltage and the motor shaft angular positions. The motor line currents are measured, and converted to voltage signals, which are then converted into digital values by the $A / D$ sub-system module for the current control loop. An optical incremental encoder is installed at the motor shaft. The encoder generates 2048 pulses per revolution. By using a multiplier of four logic circuits, which are built in the board, the encoder output pulses are increased to 8192 pulses per revolution. A 32-bit counter is used to count the encoder pulses and is read by a calling function in the software. The counter is reset once per revolution by the index pulse that is generated from the encoder. The actual motor speed is deduced from the measured shaft position. However, the estimated motor speed is obtained by the proposed algorithm. To execute the speed control loop algorithm. a discrete transfer function of the speed 
controller is used. The difference equation of the system can be developed and the torque command can be computed. Then the difference between the torque command and the calculated torque is passed through a three-level comparator. Also, the difference between the flux command and the calculated flux is passed through a two-level comparator.

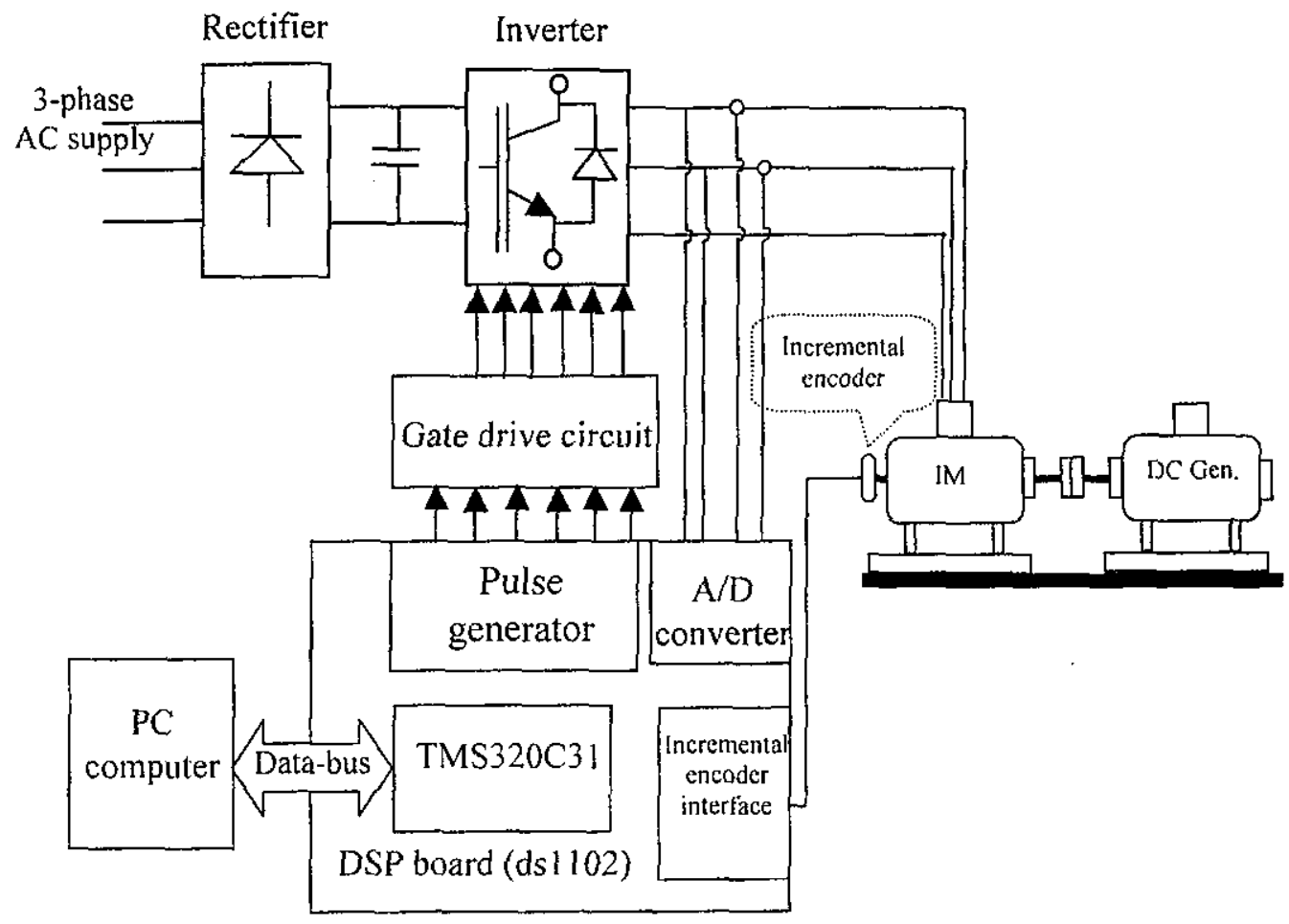

Fig. (5) Control system hardware implementation

\section{SIMULATION AND EXPERIMENTAL RESULTS:}

In order to verify the steady state and dynamic performance of the proposed system, simulation has been carried out with sampling period $100 \mu \mathrm{sec}$. The first parts of the results have been investigated for speed command of $390 \mathrm{rpm}$ at no load. Figure (6) emphasizes the good performance of the drive system with regard to implementation of the DTC technique. The stator motor currents have a sinusoidal waveform as shown in Fig.(6-a,b,c). In Fig.(6-d), it is observed that the electromagnetic torque follows its reference. The torque ripple is about $0.1 \mathrm{Nm}$, which is rather low for a DTC motor drive system. On the other hand, the response is quite rapid, and the system reaches its steady state in less than $0.3 \mathrm{sec}$. Figure $(6-\mathrm{e})$ shows estimated and actual motor speed. It is noticed that the estimated speed is very enclose to the actual motor speed. Figure(6-1) shows the stator q-axis flux versus d-axis flux trajectory in the stationary reference frame. After an initial transient, the locus of stator flux quickly becomes a circle, where the amplitude of the stator flux can perfectly track the commanded value. 


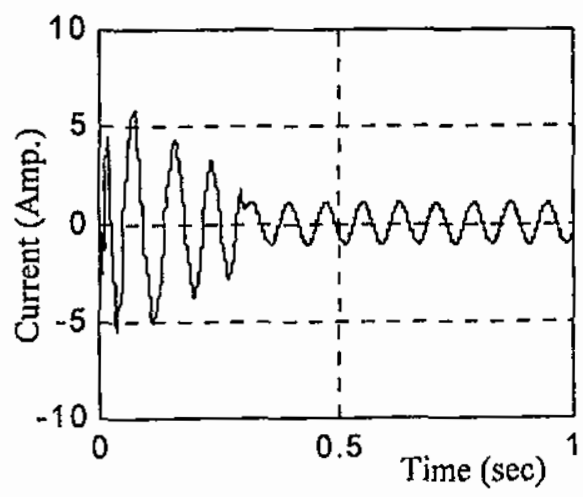

Fig.(6-a) Stator current in phase-a

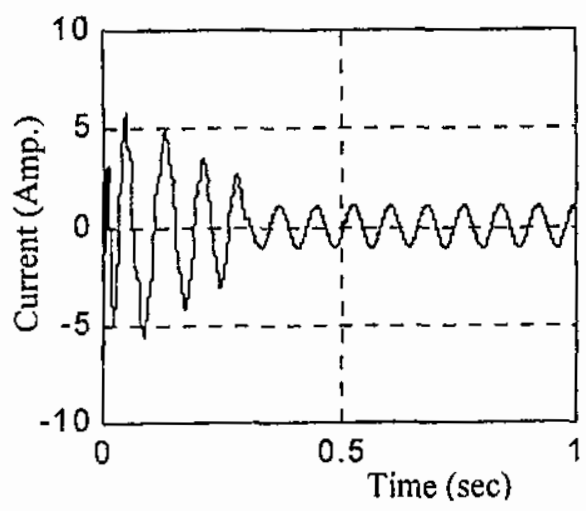

Fig. (6-c) Stator current in phase-c

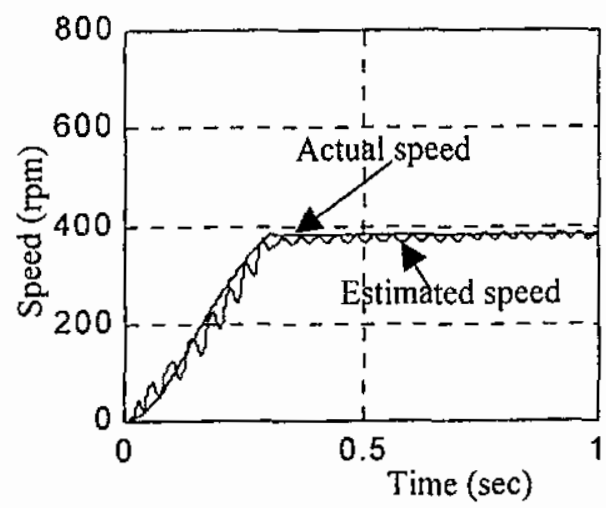

Fig.(6-e) estimated and actual speed

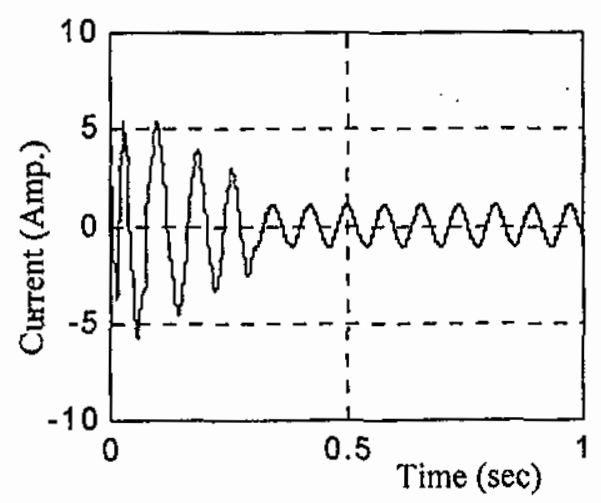

Fig.(6-b) Stator current in phase-b

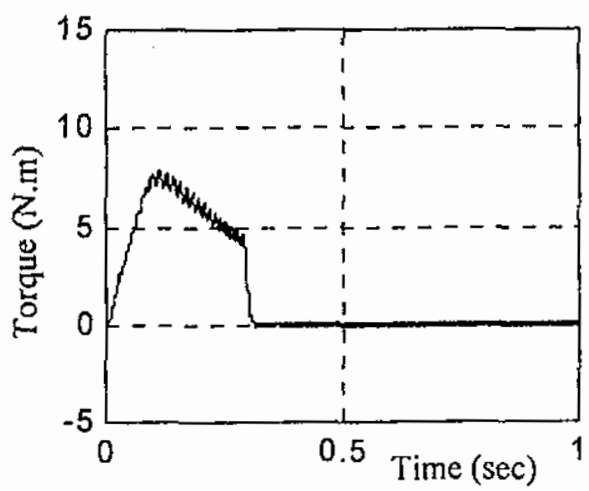

Fig.(6-d) Developed torque

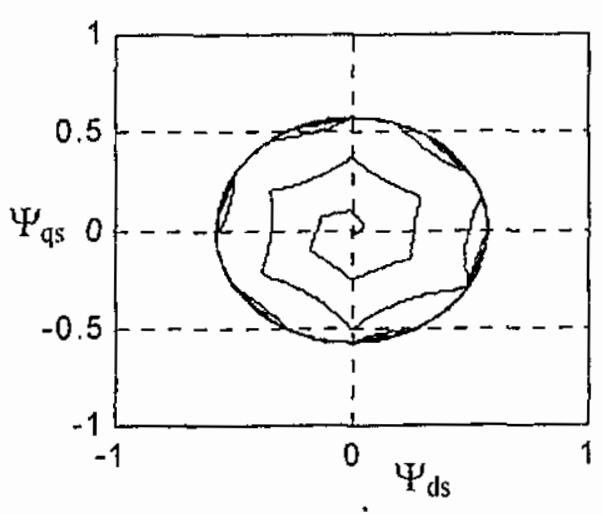

Fig.(6-f) Stator flux trajectory

Fig.(6) Proposed system performance at speed command $390 \mathrm{rpm}$

The transient performance of the proposed control scheme has been tested with a load torque of $3 \mathrm{~N} . \mathrm{m}$. and with a speed command of $1000 \mathrm{rpm}$. The flux command is $0.55 \mathrm{wb}$. Fig.(7) shows the performance of the proposed system at high speed. The actual and estimated speed shows a good response and the current waveforms are nearly sinusoidal. 


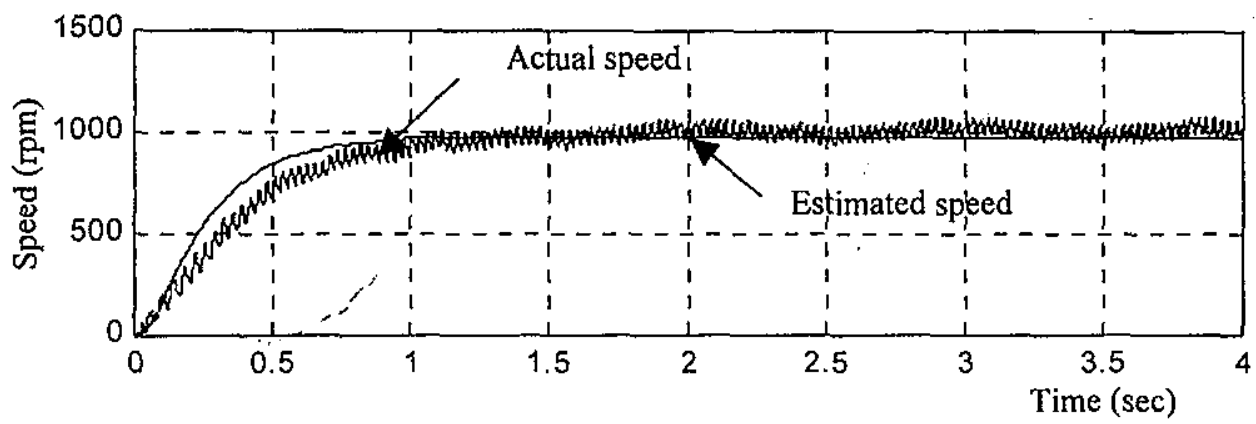

Fig.(7-a) Actual and estimated motor speed at steady state

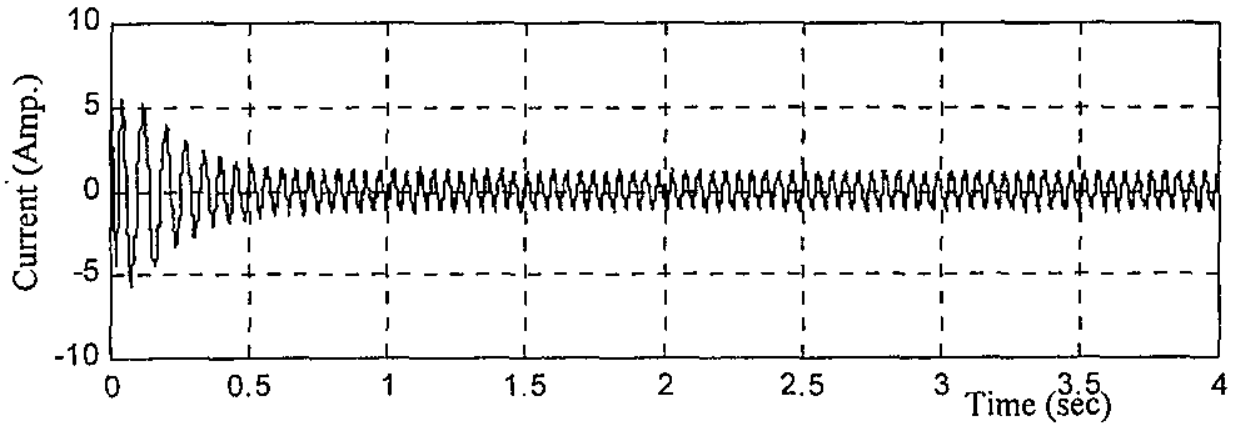

Fig.(7-b) Stator current in phase-a

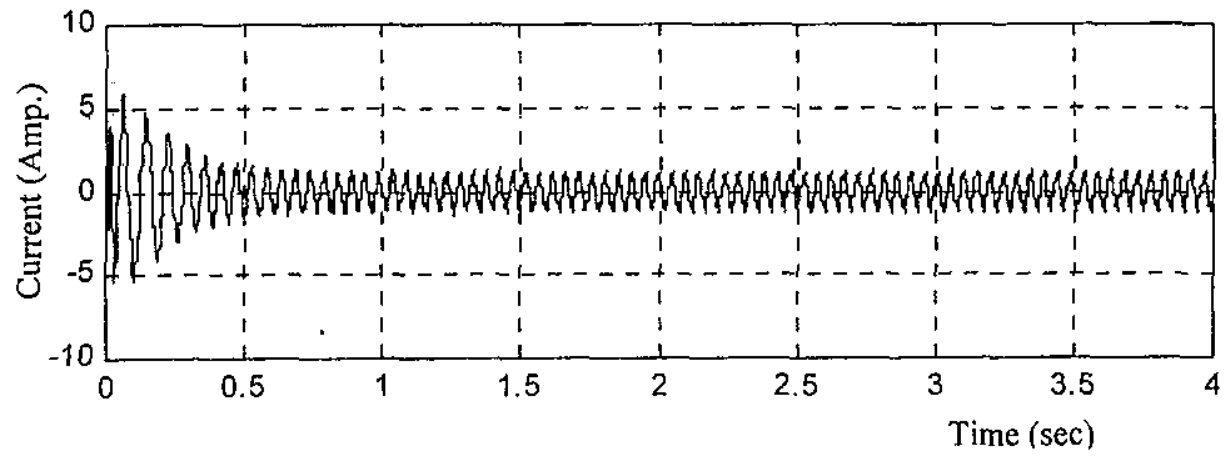

Fig.(7-c) Stator current in phase-b

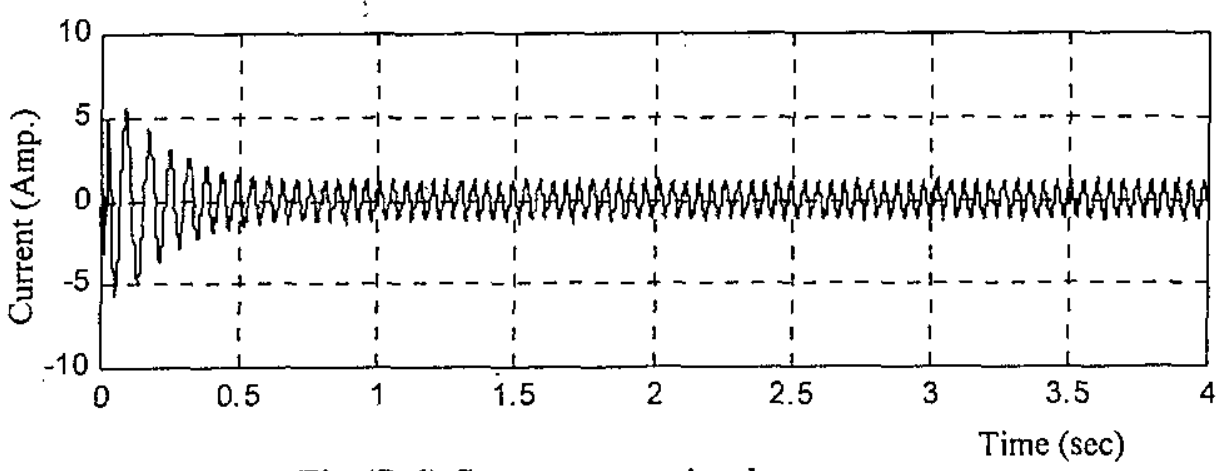

Fig.(7-d) Stator current in phase-c 


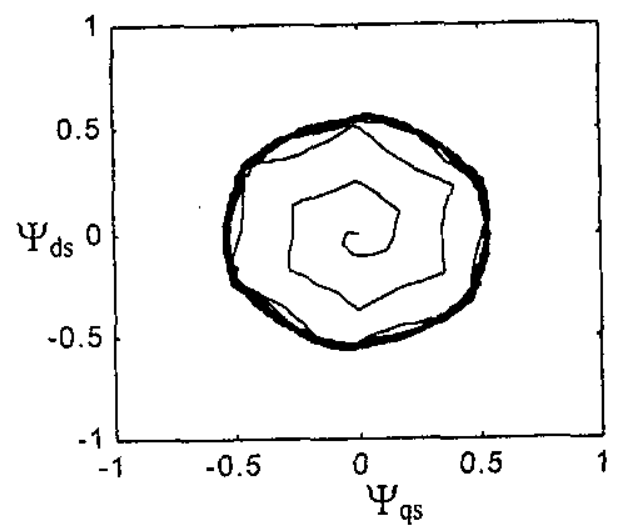

- Transient response

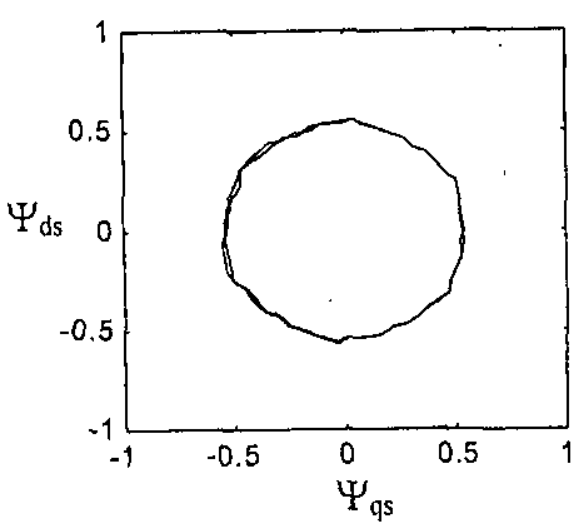

- Steady state response

Fig.(7-e) Stator flux trajectory.

Fig.(7) Performance of the proposed system at a speed command of $1000 \mathrm{rpm}$

The experimental results have been investigated in the high, medium, and low speed range.

- High speed results:

Figure (8) shows the performance of the system at a speed command of 1000 rpm. Figure(8-a) shows the motor speed and stator currents in phases $a, b$, and $c$. It appears that the stator currents and motor speed have a soft dynamic response, and quickly reach the steady state. Figure (8-b) shows the voltages in phases a, $b$, and c. Figure( $8-c)$ shows the stator current, and voltage in $d$ and $q$ axis.

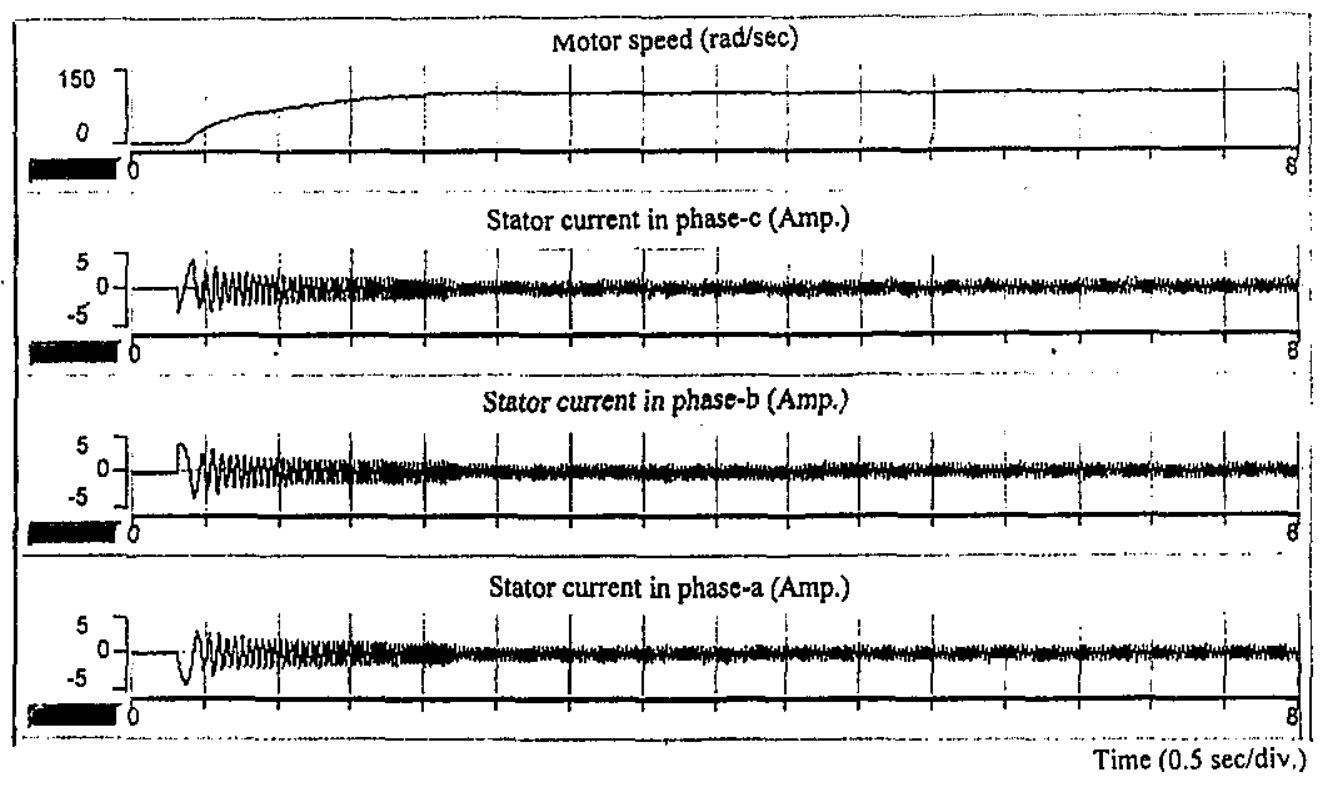

(a) Motor speed, and stator current in phase-a, b, and c 


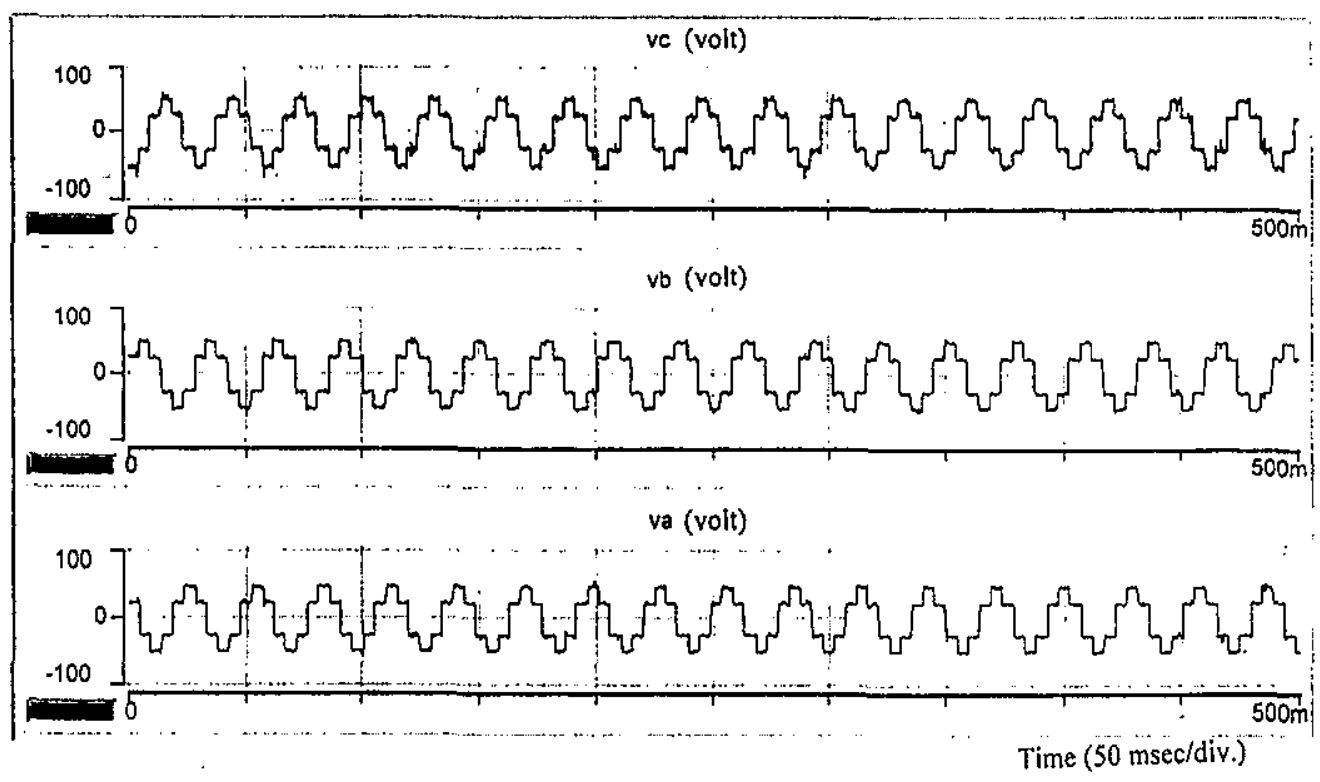

(b) Stator voltage in phase-a, b, and c

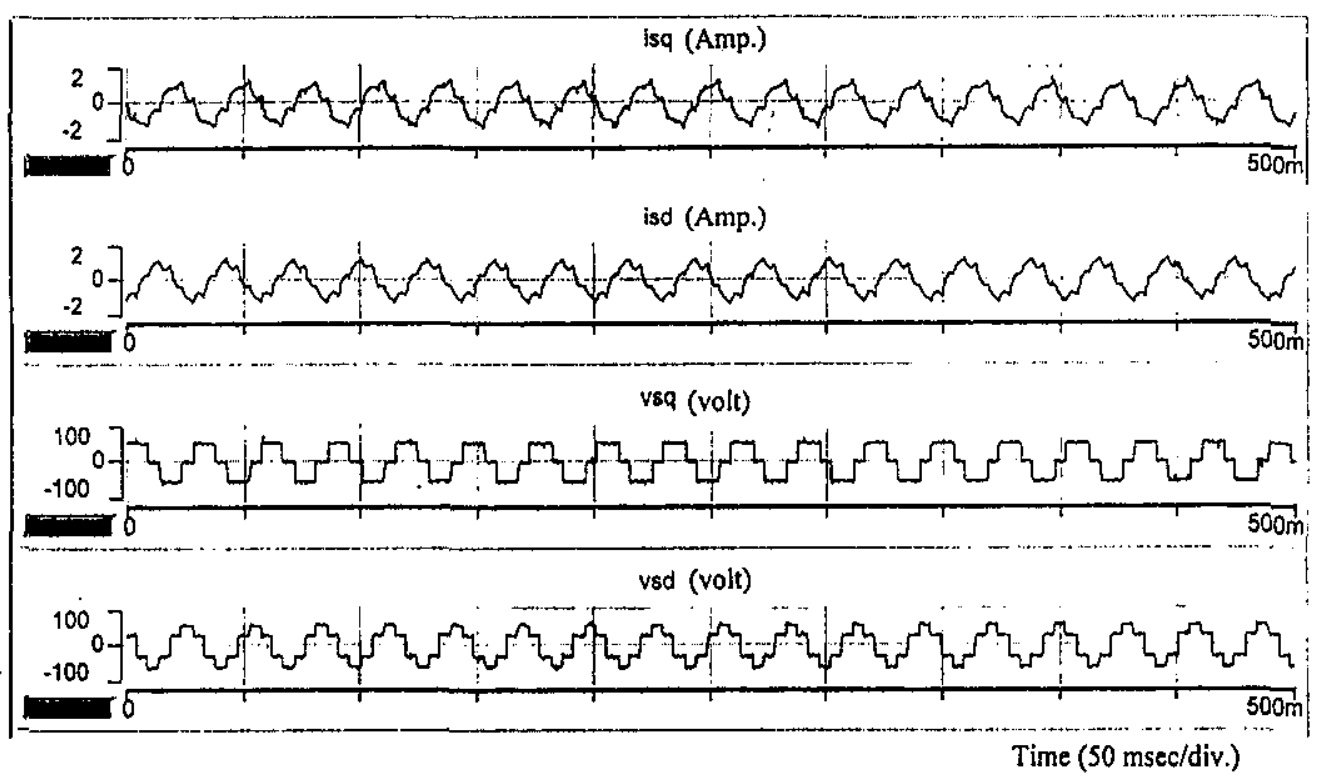

(c ) d-q axis of stator current and voltage

Fig.(8) Experimental results for a speed command of $1000 \mathrm{rpm}$.

- Medium speed results:

Figure (9) shows the system performances at a speed command of $500 \mathrm{rpm}$. 


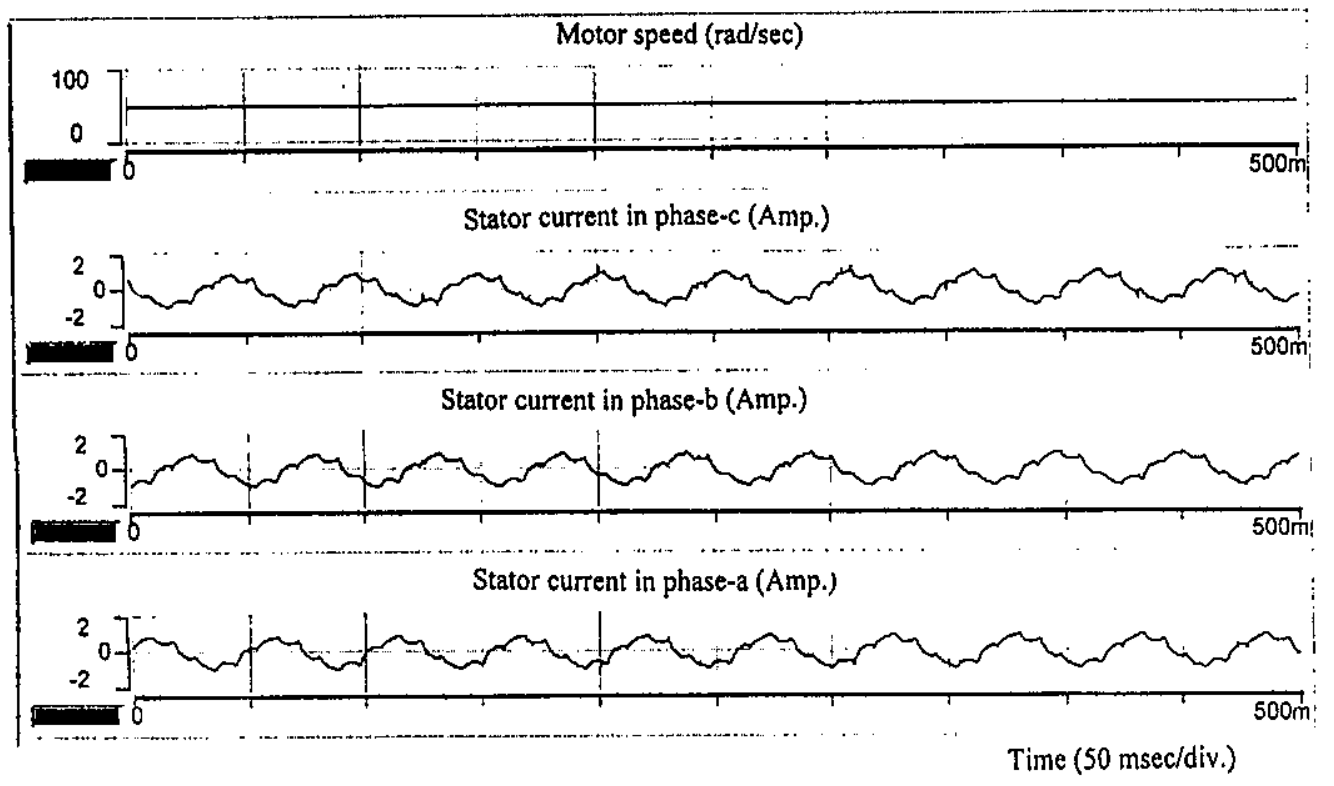

Fig.(9) Experimental results for a speed command of $500 \mathrm{rpm}$

\section{- Low speed results:}

The performances of the proposed drive system have been tested also at low speed. The speed command is $300 \mathrm{rpm}$ Figure (10) shows the results obtained. As can be seen, even at low speed, the stator currents have sinusoidal waveforms.

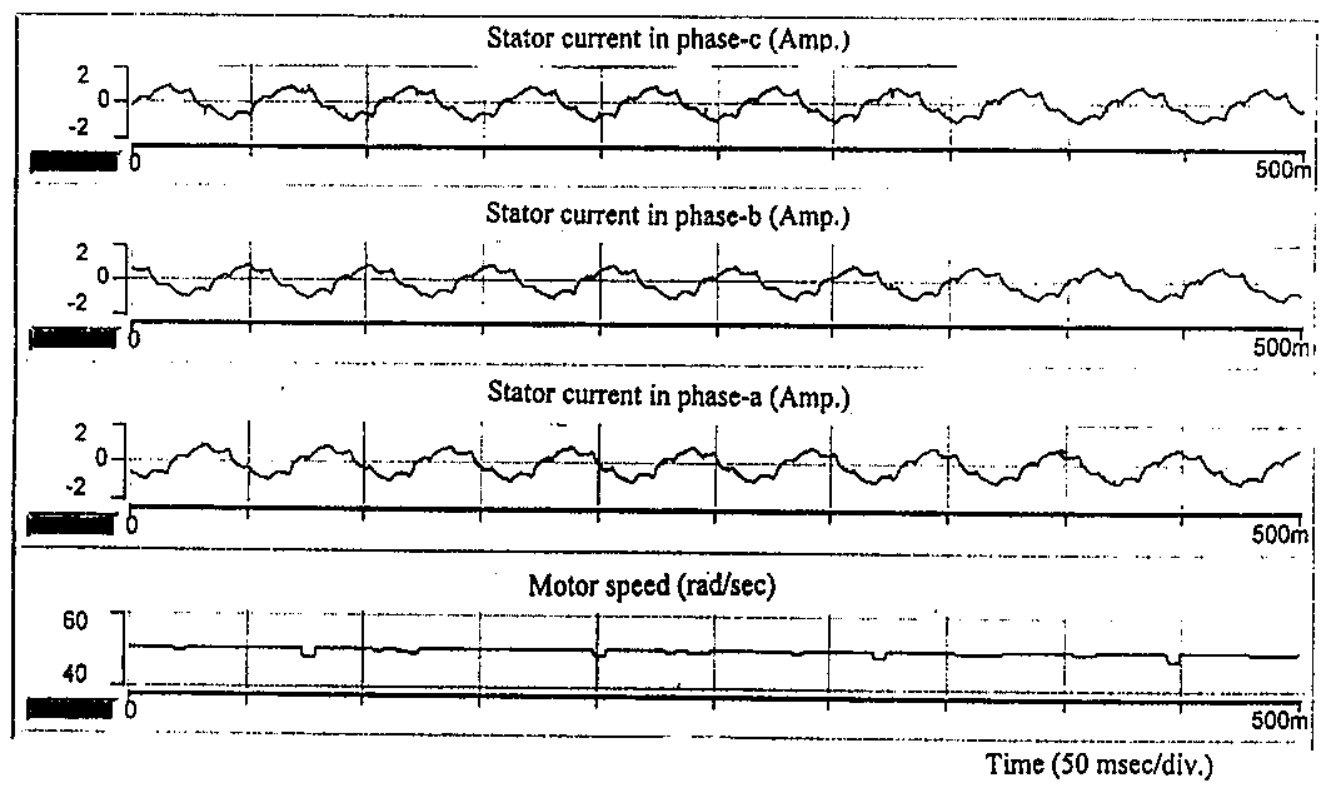

Fig.(10) Experimental results for a speed command of $300 \mathrm{rpm}$ 
Therefore, experimental results further demonstrate that DTC has higher dynamic and steady'state performance, which is consistent with the theoretical analysis and simulation results obtained previously.

\section{CONCLUSION:}

A system has been proposed enables to drive an induction motor at various speeds without a speed sensor. The proposed control scheme has been tested at run-up and steady state conditions with variable speed range. The current and torque waveforms emphasis the effectiveness of the control scheme. The simulation and experimental results confirm the advantages of the proposed control system, which has constant switching frequency, uni-polar voltage PWM, very low torque and current distortion, no sector change distortion, very fast torque and flux responses and lower sampling time. On the other hand, the presented DTC algorithm can be successfully implemented in every fast processor unit. The obtained results are acceptable and allow the proposed system to fulfil dynamic and steady state high performance characteristics.

\section{APPENDIX:}

The induction motor under test, is a three-phase squirrel cage motor and has the following data:

$\begin{array}{ll}\text { Rated power } & : 1.1 \mathrm{~kW} \\ \text { Rated line voltage } & : 380 \text { volts } \\ \text { No. of poles } & : 4 \\ \text { Stator resistance } & : 7.4826 \mathrm{ohm} \\ \text { Rotor resistance } & : 3.6840 \mathrm{ohm} \\ \text { Mutual inductance } & : 0.4114 \mathrm{Henry} \\ \text { Stator leakage inductance } & : 0.0221 \mathrm{Henry} \\ \text { Rotor leakage inductance } & : 0.0221 \mathrm{Henry} \\ \text { Moment of inertia } & : 0.004 \mathrm{Kg} \cdot \mathrm{m}^{2} . \\ \text { Supply frequency } & : 50 \mathrm{~Hz} . \\ \text { Motor speed } & : 1400 \mathrm{rpm} . \\ \text { Rated load torque } & : 7.5 \mathrm{~N} . \mathrm{m} .\end{array}$

\section{REFERENCES:}

[1] K. D. Hurst, T. G. Habetler, G. Griva, and F. Profumo, "Zero-Speed Tacholess IM Torque Control of Stator Voltage Integration" IEEE Trans. on Industry Applications, Vol. 34, No. 4, pp. 790-795, July/August 1998.

[2] J. K. Seok, J. S. Kim, and S. K. Sel, " Overmodulation Strategy for HighPerformance Torque Control" IEEE Trans. on Power Electronics, Vol. 13, No. 4, pp. 786-792, July 1998. 
[3] M. Iwasaki, and N. Matsui, "Robust Speed Control of IM with Torque Feedforward Control" IEEE Trans. on industrial Electronics, Vol. 40, No. 6, pp. 553-560, December 1998.

[4] J. I. Ha, and S. K. Sul, "Sensorless Field-orientation Control of an Induction Machine by High-Frequency Signal Injection" IEEE Trans. on Industry Applications, Vol. 35, No. 1, pp. 45-51, January/February 1999.

[5] C. Schauder, "Adaptive Speed Identification For Vector Control Of Induction Motors Without Rotational Transducers" IEEE/LAS Annual Meeting, pp. 493-499, 1989.

[6] F. Z. Peng, T. Fukao, and J. S. Lai, "Low-Speed Performance of Robust Speed Identification Using Instantaneous Reactive Power for Tacholess Vector Control of Induction Motors" IEEE/IAS Annual Meeting, pp. 509-514, 1994.

[7] T. Aihara, A. Toba, T. Yanase, A. Mashimo, and K. Endio, "Sensorless Torque Control of a salient-Pole Synchronous Motor at Zero-Speed Operation" IEEE Trans. on Power Electronics, Vol. 14, No.1, pp. 202-208, January 1999.

[8] M. Depenbrock, F. Hoffmann, and St. Koch, "Speed Sensorless High Performance Control For Traction Drives" 7th EPE Conference Trondheim 1997, Conf. Rec. Vol. 1, pp. 1.418-1.423, 1997.

[9] F. Hoffmann, and St. Koch, "Steady State Analysis of Speed Sensorless Control of Induction Machines" IECON '98 (Aachen), Conf. Rec. Vol, 3, pp. $1626-1631,1998$.

[10] M. Depenbrock, Ch. Foerth, and St. Koch, "Speed Sensorless Control Of Induction Motors At Very Low Stator Frequencies" 8th European Power Electronic Conference (EPE), Lausanne 1999.

[11] I. Takahashi and T. Noguchi, "A new Quick Response And High Efficiency Control Strategy of An Induction Motor "IEEE Transaction Industry Applications, Vol. IA-22, No.5, PP. 820-827, Sept./Oct. 1986.

[12] DSP CIT Hardware, "DSPACE Digital Signal Processing and Control Engineering GMBH" Germany 1993. 
التحكم المباشر فى العزم لتسييز آله تأثيرية بدون إستخدام جهاز إحساس

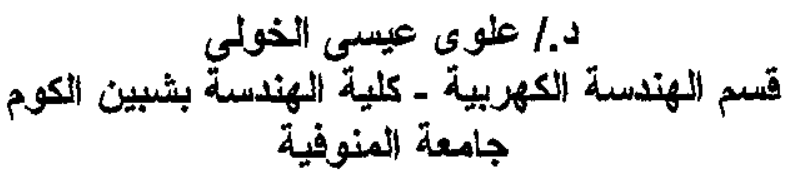

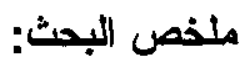

يقدم هذا البحث إقتر احا لنظلام التحكم فى العزم و السرعة بواسطة مغير يعمل بتعديل

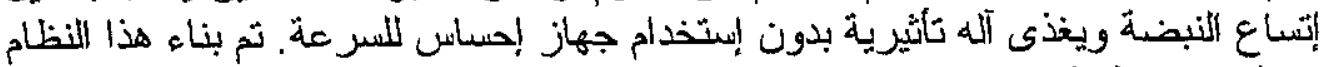

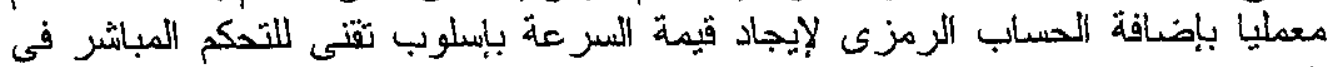
اللعزم القائم على نظرية التحكم بمتجه اللفر اغ اللحظى العنى.

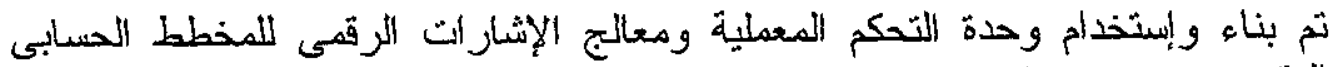

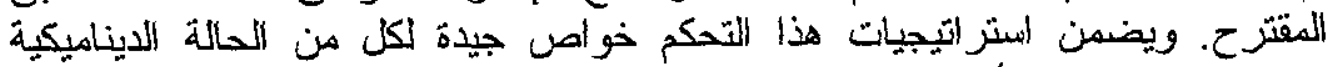

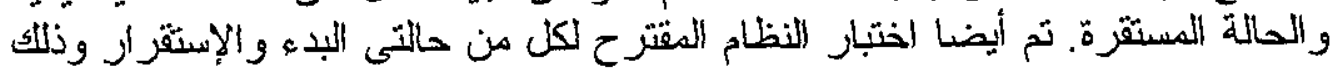

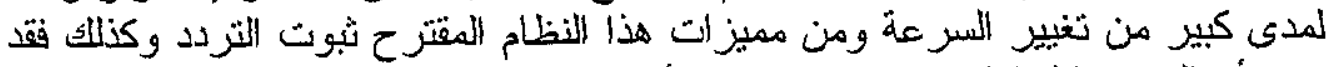

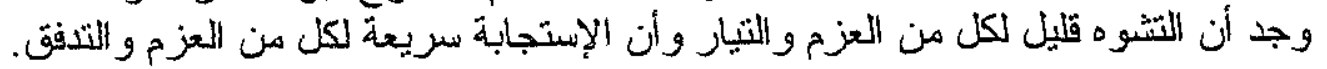

تم إبنعر اض نتائج الدراسة المعلية و النظرية ومقارنتنها معا تحت ظروف تشغيل مختلفة فوجد نطابق كبير بينهما مما يؤكد صحة الدان السات النظرية. 